\title{
Proximate Compositions and Biological Activities of Caulerpa lentillifera
}

\author{
Risa Nofiani*1, Sigit Hertanto ${ }^{1}$, Titin Anita Zaharah ${ }^{1}$, and Sutarman Gafur ${ }^{2}$ \\ ${ }^{1}$ Department of Chemistry, Faculty of Mathematics and Natural Sciences, \\ Universitas Tanjungpura, Pontianak, Indonesia \\ ${ }^{2}$ Department of Soil Science, Faculty of Agriculture, Universitas Tanjungpura, \\ Pontianak, Indonesia \\ *email: risa.nofiani@chemistry.untan.ac.id,rnofiani@yahoo.com
}

Received September 14, 2018; Accepted November 25, 2018; Available online December 8, 2018

\begin{abstract}
Caulerpa lentillifera is an edible and functional seaweed due to its high nutritional compositions and its biological activities. In this study, C. lentillifera was evaluated for its proximate compositions (moisture, ash, protein, lipid and fiber contents) and its biological activities (antimicrobial, anti-oxidant, and toxicity). Moisture content, crude lipid, crude protein, and crude fiber were determined using oven method, soxhlet extraction, semi-micro Kjeldhal, and hydrolysis, respectively. Fresh C. lentillifera of Natuna Island, Indonesia, showed its higher level content of ash, crude lipid, and crude fiber compared to that of fresh $C$. lentillifera of Penghu, Taiwan. For its biological activity assays, the extracts were prepared from fresh and dry C. lentillifera (FC and DC). Both of the extracts showed the broad spectrum of weak antimicrobial using well-diffusion agar tests and antioxidant activities using a modified linoleic acid emulsion system. The toxicity for both extracts was determined using brine shrimp lethality test. DC extract showed its very low toxicity level and there was no toxicity for FC. Hemolytic activity was determined using red blood assay. Both extracts showed their low hemolytic activities (about 5-13\%) for the concentration of 100 and 150 $\mu \mathrm{g} / \mathrm{mL}$, but the activity increased sharply (about 96\%) on the concentration of $200 \mu \mathrm{g} / \mathrm{mL}$. It was concluded that $C$. lentillifera has a potency as a functional food due to containing secondary metabolites with various biological activities.
\end{abstract}

Keywords: Caulerpa lentillifera, antimicrobial and antioxidant activity, toxicity, hemolysis, proximate composition

\section{INTRODUCTION}

Seaweeds have high nutritional constituents consisting of essential minerals, fatty acids, dietary fibers, amino acids and vitamins (Bhuiyan, Qureshi, Kamal, Aftab, \& Siddique, 2016). Studies about chemical composition and nutritive value of edible seaweeds have increased due to their potential for food uses. For example, $C$. lentillifera from Malaysia and Thailand were reported having the nutritional composition such as: proximate composition, amino acids, vitamin $\mathrm{C}$ and $\mathrm{E}$ (Matanjun et al, 2009; Ratana-arporn and Chirapart, 2006). It was also reported that dry C. lentillifera (DC) which can be used as sources of food protein due to its high protein levels and balanced amino acid profiles (Ratana-arporn \& Chirapart, 2006)

C. lentillifera is a green edible seaweed, classified into a Chlorophyta marine macroalgae (Mohamed, Hashim, \& Rahman, 2012). It is widespread in Asian countries such as: Indonesia, Japan, Thailand, Malaysia, China, Philiphine, Korea and some other countries in Southeast Asia (Nguyen, Ueng, \& Tsai, 2011).
In Natuna Island, Indonesia, $C$. lentillifera is naturally grown and known as Latuh and it is used to be consumed as a fresh salad, although it is lately rarely consumed by the community of Natuna.

In addition to its good nutritional composition, the genus Caulerpa is known rich in its bioactive compounds with various biological activities. These properties make it be potentially used as a functional food. Caulerpa racemose has anti-microbial activities due to its bioactive compounds content known as: caulerpin, sterol, and caulerpicin (Doty and Aguilar-santos, 1970; Doty 1966). Caulerpa ashmeadii contains high concentrations of sesquiterpenoid showing their anti-microbial and ichthyotoxicity activities (Paul, Littler, Littler, \& Fenical, 1987). Caulerpa taxipolia and the other Caulerpa containing caulerpenyne showed their cytotoxic activities (Dumay, Erard, Pergent-martini, \& Amade, 2002). C. lentillifera combined with Hibiscus rosasinensis, and Piper sarmentosum showed their antipyretic activities (Daud, Fazuliana, Arsad, 
Ismail, \& Tawang, 2016). Extract of $C$. lentillifera has the potency to be used as an anti-diabetic agent.

A seaweed grown in different location, habitat, or environmental conditions, and harvested in different maturity levels had caused the different in its chemical compositions, consistency, color, quality, and its bioactive compounds (Ito and Hori 2009; Kilınç et al. 2013). The proximate composition of $C$. lentillifera of Malaysia and Thailand has been reported but $C$. lentillifera of Indonesia has not yet been studied and reported.

In this study, $C$. lentillifera from Natuna Island of Indonesia was evaluated for its proximate compositions as $C$. lentillifera fresh because it is eaten fresh in the community of Natuna. For its biological activities particularly for its antimicrobial, anti-oxidant, and its toxicity activities was also analyzed as fresh and dry $C$. lentillifera which probably benefit for health or is called as a functional food.

\section{EXPERIMENTAL SECTION}

\section{Sampling}

C. lentillifera was collected randomly from the coastal area of Kabupaten Natuna, Kepulauan Riau. Morphology of C. lentillifera was identified in the Laboratory of Biology, Faculty of Mathematics and Natural Sciences, Universitas Tanjungpura, Indonesia.

\section{Preparation of $C$. lentillifera}

Fresh $C$. lentillifera $(\mathrm{FC})$ was rinsed using distilled water and used directly for its proximate analysis and biological activity assays. Dry C. lentillifera (DC) were prepared by drying of $C$. lentillifera directly under the sunshine. The FC was used for proximate analysis, while the FC and DC were used for its antioxidant, hemolysis, cytotoxicity and antimicrobial assays.

\section{Proximate Analysis}

Moisture content was determined using oven method based on Method of 925.10 from AOAC. Ash content was determined based on Method number of 08-01 from AOAC. Crude lipid was determined using Soxhlet extraction with diethyl ether referred to Method of 30-25, AOAC. Crude fiber was determined using successive hydrolysis with $100^{\circ} \mathrm{C} 1.25 \%$ of $\mathrm{H}_{2} \mathrm{SO}_{4}$ and $3.25 \%$ of $\mathrm{NaOH}$ for 30 min each based on SNI 01-2891-1992. Crude protein was determined using semi-micro Kjeldhal methods referred to SNI (Indonesian National Standard 01-2891-1992).

\section{Extraction of C. lentillifera}

The FC (139.6 g) was ground using a a mortar and macerated using $80 \%$ of ethyl acetate. The maceration was carried out many times until colorless filtrate. The filtrate was evaporated using a rotary evaporator to get crude extract FC. The DC powder $(21.6 \mathrm{~g})$ was macerated using of methanol $80 \%$ until colorless filtrate. The filtrate was evaporated using a rotary evaporator to get crude extract DC.

\section{Antimicrobial Test}

Both extracts (FC and DC) were screened antimicrobial activities using welldiffusion methods (Okeke, Iroegbu, Eze, Okoli, \& Esimone, 2001). Tested microorganisms were cultured by inoculation onto $10 \mathrm{~mL}$ of nutrient broth (NB) medium and incubated on a rotary shaker incubator at 130 $\mathrm{rpm}$ at $30{ }^{\circ} \mathrm{C}$ for $14-16 \mathrm{~h}$. The culture was added on nutrient agar (NA), mixed and poured into the plate. After gel solid, the medium was punched using a sterilized pipette with diameter $0.4 \mathrm{~mm}$. The extracts (FC and DC) with various concentrations $(50,100,200$, 400 , and $500 \mu \mathrm{g} /$ well) were poured into the well. After solvent from the extract was evaporated, the plate was incubated for 14-16 hours.

The extract having antimicrobial activities was signed with the formation of inhibition zone around the well then the diameter of inhibition zone (measured from the edge of the colony to the edge of the clear zone) was recorded. Furthermore, the extract having antimicrobial activities was tested for its bacteriostatic and bactericidal activities by the measuring its inhibition zone. Minimum inhibition concentrations (MICs) of each extract was counted based on the method of Bonev et al. (Bonev, Hooper, \& Parisot, 2008).

\section{Antioxidant Assay}

The antioxidant assay was carried out using a slight modified linoleic acid emulsion system (Loganayaki, Siddhuraju, \& Manian, 2013). A $10 \mu \mathrm{L}$ of linoleic acid was mixed with $1 \mathrm{~mL}$ of ethanol in Eppendorf tube. The mixture was added with $1000 \mu \mathrm{g}$ extract of $C$. lentillifera and incubated in the dark room at $25{ }^{\circ} \mathrm{C}$. 


$$
\% \text { of } \mathrm{AA}=1-\frac{(\text { Sample absorbance at } 24 \mathrm{~h}-\text { sample absorbance at } 0 \mathrm{~h})}{(\text { Blank absorbance at } 24 \mathrm{~h}-\text { blank absorbance at } 0 \mathrm{~h})} \times 100 \%
$$

After 24 hours, the mixture was added with $20 \mu \mathrm{L}$ of $\mathrm{FeSO}_{4} 0.014 \mathrm{M}$ and $20 \mu \mathrm{L}$ of KSCN After $3 \mathrm{~min}$, the absorbance was measured at $490 \mathrm{~nm}$. A blank absorbance was measured at $\mathrm{t}=0 \mathrm{~h}$ and $\mathrm{t}=24 \mathrm{~h}$. Vitamin $\mathrm{C}$ $(1000 \mu \mathrm{g})$ was used as a positive control. The antioxidant activity (AA) was calculated as a persentage of inhibition relative to the control using the Equation 1.

Erythrocyte suspensions were prepared according to Situ \& Bobek (2000) and Saengkhae et al. (2007). Cow blood was collected using a sterile container and added with an equal volume of Alsever's solution. The blood was centrifuged at $1.500 \times \mathrm{g}$ for 5 menit with a temperature of $4{ }^{\circ} \mathrm{C}$. The pellet was washed three times with 10 volumes of phosphate buffer saline (PBS; $125 \mathrm{mM}$ of $\mathrm{NaCl}, 10 \mathrm{mM}$ of sodium phosphate buffer, $\mathrm{pH}$ 7.4). The pellet was resuspended in PBS solution and adjusted to a hematocrit of $1 \%$.

\section{Hemolytic Assay}

The hemolytic assay was carried out using a red blood cell (Situ \& Bobek, 2000; Saengkhae et al. 2007). A $100 \mu \mathrm{L}$ of erythrocytes $1 \%$ was mixed with the extracts of FC and DC (100, 150 dan $200 \mu \mathrm{g} / \mathrm{mL})$ and incubated at $37{ }^{\circ} \mathrm{C}$. After $30 \mathrm{~min}$, the mixture was centrifuged at $1500 \mathrm{x} \mathrm{g}, 4{ }^{\circ} \mathrm{C}$. Cell lysis was monitored by measuring the release of hemoglobin at $540 \mathrm{~nm}$ using a Microplate reader. As a positive and negative control was used $1 \%$ of sodium dodecyl sulfate (SDS) in PBS and PBS alone, respectively. Percentage of hemolysis was calculated as follows: [ $\left(\mathrm{A}_{540}\right.$ of the sample treated with the extract- $\mathrm{A}_{540}$ sample treated with buffer $)] /\left[\left(\mathrm{A}_{540}\right.\right.$ of the sample treated with $\mathrm{SDS}-\mathrm{A}_{540}$ sample treated with buffer)] x $100 \%$.

\section{Preliminary Toxicity Test}

Preliminary toxicity test was carried out using Brine Shrimp Lethality Test (BSLT) (Meyer et al., 1982). Ten shrimps Artemia salina Leach, of 2 days old, were added with the extracts of various concentrations ( 0 (for control), 10, 100, 200, 400, 600, 800 dan 1.000 $\mu \mathrm{g} / \mathrm{mL}$ ) and with artificial sea water (3 $\mathrm{mg}$ in 5 $\mathrm{ml}$ artificial sea water) to make a $9 \mathrm{~mL}$ solution. After 24 hours at room temperature, the nauplii survivors can be counted macroscopically and the percent deaths at each dose and control were determined. The percentage of death was counted based on Abbott's formula (Abbot, 1925).

$$
\% \text { deaths }=[(\text { test }- \text { control }) / \text { control }] \times 100
$$

\section{Statistical Analysis}

The data were subjected to a one-way analysis of variance (ANOVA) and the significance of the difference between means was determined by LSD $(\mathrm{P}<0.05)$ using SPSS version 23 (Kokoska, 2015). Values expressed are means of three replicate determinations \pm standard deviation.

\section{RESULTS AND DISCUSSION}

\section{Proximate Composition of $C$. lentillifera}

Proximate composition of FC from Natuna District of Indonesia was different than that of FC from Penghu of Taiwan except for the moisture content (Table 1).

Table 1. Proximate Compositions of C. lentillifera from Natuna District (\% FC)

\begin{tabular}{lcc}
\hline \multicolumn{1}{c}{$\begin{array}{c}\text { Proximate } \\
\text { Composition }\end{array}$} & \multicolumn{2}{c}{ Percentage of FC from } \\
\hline \multicolumn{1}{c}{ Noisture } & Natuna, Indonesia & Penghu, Taiwan (Nguyen et al., 2011) \\
Ash & $95.01 \pm 0.170$ & $94.28 \pm 0.24$ \\
Crude Lipid & $3.41 \pm 0.160$ & $1.27 \pm 0.02$ \\
Crude Protein & $0.79 \pm 0.002$ & $0.09 \pm 0.01$ \\
Crude fiber & $0.43 \pm 0.007$ & $0.53 \pm 0.02$ \\
Carbohydrate (exclude & $14.38 \pm 3.640$ & $0.17 \pm 0.01$ \\
crude fiber)** & $0.36 \pm 0.025$ & $3.67 \pm 0.07$ \\
\hline
\end{tabular}

Values are presented as mean $\pm \mathrm{SD}(\mathrm{n}=3)$. ** Calculate by difference ( $\%$ carbohydrate $=100 \%-\%$ moisture- $\%$ crude protein- $\%$ crude lipid- $\%$ ash $-\%$ crude fiber $)$. 
Table 2. Antimicrobial Activities of the extract DC and FC against Tested Microorganism

\begin{tabular}{lcc}
\hline \multirow{2}{*}{ Microorganism Tests } & \multicolumn{2}{c}{ MIC of Extract $(\boldsymbol{\mu g} / \mathbf{w e l l})$} \\
\cline { 2 - 3 } & DC & FC \\
\hline E. coli & - & 500 \\
S. aureus & 400 & 500 \\
B. subtilis & 200 & 50 \\
V. cholerae & 50 & 500 \\
C. freundii & 500 & 400 \\
V. harveyi & 500 & 500 \\
V. vara & - & 100 \\
Salmonella sp. & 500 & - \\
P. aeruginosa & - & 500 \\
A. hydrophila & 500 & 500 \\
Bacillus sp. & 200 & - \\
K. pneumoniae & 200 & 500 \\
C. albicans & 400 & 500 \\
\hline
\end{tabular}

Note: -: no antimicrobial activities

FC from Natuna had generally higher levels of ash, crude lipid, and crude fiber compared with that of FC from Penghu of Taiwan. DC of Malaysia, Taiwan, and Thailand showed a generally different of their proximate composition (Nguyen et al., 2011; Ratana-arporn and Chirapart, 2006; Matanjun et al., 2009). It might be due to the different in their habitat conditions, maturity levels, and their environmental conditions (Ito \& Hori, 2009).

\section{Antimicrobial Activity}

In general, extract $C$. lentillifera $\mathrm{FC}$ and DC showed the broad spectrum of weak antimicrobial activities against tested microorganisms (E. coli, S. aureus, B. subtilis, $V$. cholerae, $C$. freundii, $V$. harveyi, $P$. aeruginosa, A. hydrophila, K. pneumoniae and $C$. albicans) based on their high minimum inhibition concentration (MIC) value (Table 2). The broad spectrum of antimicrobial activities was also shown by the other extract of Caulerpa such as: $C$. ashmeadii, $C$. paspaloides and C. prolifera (Freile-pelegrin \& Morales, 2004). C. cupressoides, C. Mexicana, and $C$. racemose showed their antimicrobial activities towards Bacillus subtilis (Freile-pelegrin \& Morales, 2004). Caulerpin and caulerpenyne were probably contributed to antimicrobial activities of $C$. lentillifera which is commonly to occur in Caulerpa (Paul et al., 1987).

\section{Hemolytic Assay}

The hemolytic assay can be used for toxicity studies of compounds (Situ and Bobek 2000; Djouossi et al. 2015). The advantages using of this assay is it is sensitive, cheap, quick, and easy to monitor the lysis. Both extracts of FC and DC showed its low hemolytic activities (around 5-13\%) for concentrations of 100 and $150 \mu \mathrm{g} / \mathrm{mL}$, but the activity increases sharply (about 96\%) for both concentration of $200 \mu \mathrm{g} / \mathrm{mL}$ (Table 3). The hemolytic activity will probably damage the red cell of the membrane and induces the hemolytic anemia (Zohra and Fawzia 2014). This activity probably results from the astringent phenolic content of $C$. lentillifera (Nguyen et al. 2011; Singh \& Kaur 2008). According to this result, $C$. lentillifera is not recommended to be consumed in excessive amount.

Table 3. Hemolytic activitiy of the extract $C$. lentillifera

\begin{tabular}{lccc}
\hline \multirow{2}{*}{ Sample } & \multicolumn{4}{c}{ Pencentage of Hemolysis for Concentration $(\boldsymbol{\mu g} / \mathbf{m L})$} \\
\cline { 2 - 4 } & $\mathbf{1 0 0}$ & $\mathbf{1 5 0}$ & $\mathbf{2 0 0}$ \\
\hline Extract FC & $13.32 \pm 0.23 \mathrm{a}$ & $13.48 \pm 0.27 \mathrm{a}$ & $96.71 \pm 1.40 \mathrm{~b}$ \\
Extract DC & $5.11 \pm 0.56 \mathrm{a}$ & $9.20 \pm 1.43 \mathrm{~b}$ & $96.22 \pm 1.77 \mathrm{c}$ \\
\hline
\end{tabular}

Values are presented as mean $\pm \mathrm{SD}(\mathrm{n}=3)$. Values with different superscript in each column are significantly different from one another $(\mathrm{p}<0.05)$ 
Table 4. Antioxidant Activity of $C$. lentillifera Extracts Using Linoleic Acid Emulsion System

\begin{tabular}{cc}
\hline Extract & \% of antioxidant activity \\
\hline DC & $54.23 \pm 2.28 \%^{\mathrm{a}}$ \\
FC & $79.09 \pm 0.78 \%^{\mathrm{b}}$ \\
Positive Control (Vitamin C) & $81.78 \pm 0.71 \%^{\mathrm{c}}$ \\
\hline
\end{tabular}

Values are presented as mean $\pm \mathrm{SD}(\mathrm{n}=3)$. Values with different superscript in each row are significantly different from one another $(p<0.05)$

\section{Brine Shrimp Lethality Test (BSLT)}

BSLT is a cheap and simple bioassay system which is used to detect a bioactive compound such as a cytotoxic drug (Meyer et al., 1982). BSLT result of both extracts of $C$. lentifera showed that was only extracted of DC caused death on larvae (nauplii) of A. salina but no extract of FC. The extract of DC gave $\mathrm{LC}_{50}$ value $258,360 \mu \mathrm{g} / \mathrm{mL}$ which was very low toxicity due to an $\mathrm{LC}_{50}$ value greater than $100 \mu \mathrm{g} / \mathrm{mL}$ (Mbwambo, Moshi, Masimba, Kapingu, \& Nondo, 2007). As a comparison, standard cytotoxic of drug (cyclophosphamide) and of gallic acid have $\mathrm{LC}_{50}$ of 531.0 and 323.6 $\mu \mathrm{g} / \mathrm{mL}$, respectively (Sonibare, 2017). According to Meyer et al., the $\mathrm{LC}_{50}$ value of extracts $\leq 1000 \mu \mathrm{g} / \mathrm{mL}$ was predicted containing bioactive compounds (Meyer et al., 1982). Caulerpenyne, a cytotoxic sesquiterpenoid, is likely responsible for this activity due to its most abundant found in the genus of Caulerpa (Dumay et al., 2002).

\section{Antioxidant Activity}

Antioxidant activity of an extract of $C$. lentillifera from Taiwan have been analyzed using various assays which are DPPH $(1,1-$ diphenyl-2-picryl hydrazyl) radical scavenging, ferric reducing, hydrogen peroxide scavenging and ferrous ion chelating (FIC) activity. The extract of $C$. lentillifera showed its low antioxidant activity compared with that of a positive control for assays using DPPH radical scavenging, ferric reducing, and hydrogen peroxide scavenging (Nguyen et al., 2011). The best antioxidant activity of the extract was resulted in using FIC assay.

In this study, the extract of $C$. lentillifera was also tested for its antioxidant activity using another method namely linoleic acid emulsion system. This system measures its inhibition of lipid peroxidation by certain compounds having antioxidant activity (Loganayaki et al., 2013). Linoleic acid is an unsaturated fatty acid with 2 double bonds which is oxidized easily to be peroxides. The peroxides are able to oxidize from $\mathrm{Fe}^{2+}$ ions to
$\mathrm{Fe}^{3+}$ ions. $\mathrm{Fe}^{3+}$ ions then react with ion thiocyanate to produce ferri thiocyanate complex $\left(\mathrm{Fe}(\mathrm{SCN})_{6}\right)$ with red color. The red color intensity showed the active peroxide formed and was measured at an absorbance of $490 \mathrm{~nm}$ wavelength.

Both extracts showed antioxidant activity, even though the antioxidant activity value of both was significantly lower $(p<0.05)$ than that of in the positive control, vitamin $\mathrm{C}$ (Table 4). According to Matanjun et. al., $C$. lentillifera also contains a low level of vitamin $\mathrm{C}$ and vitamin $\mathrm{E}$ which probably contributes to antioxidant activity in this assay (Matanjun et al. 2009; Nguyen et al. 2011).

\section{CONCLUSION}

The proximate composition of $C$. lentillifera of Indonesia was different from that of Taiwan. Ash, lipid, and fiber contents of $C$. lentillifera of Indonesia were higher than that of $C$. lentillifera of Taiwan. Furthermore, $C$. lentillifera of Indonesia also contained secondary metabolites having various biological activities, even though it is not recommended to be consumed in excessive amount. According to this study, C. lentillifera is highly recommended to be a functional food and to be a potent secondary metabolite source with various biological activities.

\section{REFERENCES}

Abbot, W. (1925). A Method of Computing The Effectiveness of an Insecticide. Journal of Economic Entomology, 18(2), 265-267.

Bhuiyan, M. K. A., Qureshi, S., Kamal, A. H. M., Aftab, U. S., \& Siddique, M. A. M. (2016). Proximate Chemical Composition of Sea Grapes Caulerpa racemosa (J. Agardh, 1873) Collected from a SubTropical Coast. Virology and Mycology, 5(2). $\quad$ https://doi.org/10.4172/21610517.1000158

Bonev, B., Hooper, J., \& Parisot, J. (2008). 
Principles of Assessing Bacterial Susceptibility to Antibiotics using the Agar Diffusion Method. Journal of Antimicrobial Chemotherapy, 61(March), 1295-1301.

https://doi.org/10.1093/jac/dkn090

Daud, D., Fazuliana, N. U. R., Arsad, M., Ismail, A., \& Tawang, A. (2016). Antipyretic Action of Caulerpa lentillifera, Hibiscus rosasinensis, and Piper sarmentosum Aqueous Extract in Mice. Asian Journal of Pharmaceutical and Clinical Research, 9(1), 9-11.

Djouossi, M. G., Tamokou, J., Ngnokam, D., Kuiate, J., Tapondjou, L. A., Harakat, D., \& Voutquenne-nazabadioko, L. (2015). Antimicrobial and Antioxidant Flavonoids from the Leaves of Oncoba spinosa Forsk. (Salicaceae). BMC Complementary and Alternative Medicine, 15, 4-11. https://doi.org/10.1186/s12906-0150660-1

Doty, S. M. (1966). Caulerpicin, a Toxic Constituent of Caulerpa. Nature, 211, 990.

Doty, S. M., \& Aguilar-santos, G. (1970). Transfer of Toxic Alga Substances in Marine Food Chains. Pacific Science, 24, 351-355.

Dumay, O., Erard, G., Pergent-martini, C., \& Amade, P. (2002). Variations in Caulerpenyne Contents in Caulerpa taxifolia and Caulerpa racemosa. Journal of Chemical Ecology, 28(2), 343-352.

Freile-pelegrin, Y., \& Morales, J. L. (2004). Antibacterial Activity in Marine Algae from the Coast of Yucatan, Mexico. Botanica Marina, 47, 140-146. https://doi.org/10.1515/BOT.2004.014

Ito, K., \& Hori, K. (2009). Seaweed: Chemical Composition and Potential Food Uses. Food Reviews International, 5(1), 101144.

K1lınç, B., Cirik, S., \& Turan, G. (2013). Seaweeds for Food and Industrial Applications. In Food Industry (pp. 735748). INTECH.

Kokoska, S. (2015). Introductory Statistics: A Problem-Solving Approach (Second). New York: W.H Freeman and Company.

Loganayaki, N., Siddhuraju, P., \& Manian, S. (2013). Antioxidant Activity and Free Radical Scavenging Capacity of Phenolic Extracts from Helicteres isora L. and
Ceiba pentandra L. Journal of Food Science and Technology, 50(4), 687-695. https://doi.org/10.1007/s13197-0110389-x

Matanjun, P., Mohamed, S., Mustapha, N. M., \& Muhammad Kharidah. (2009). Nutrient Content of Tropical Edible Seaweeds, Eucheuma cottonii, Caulerpa lentillifera and Sargassum polycystum. Journal of Applied Phycology, 21, 75-80. https://doi.org/10.1007/s10811-0089326-4

Mbwambo, Z. H., Moshi, M. J., Masimba, P. J., Kapingu, M. C., \& Nondo, R. S. O. (2007). Antimicrobial Activity and Brine Shrimp Toxicity of Extracts of Terminalia brownii roots and stem. BMC Complementary and Alternative Medicine, 7(9), 5-9. https://doi.org/10.1186/1472-6882-7-9

Meyer, B. N., Ferrigni, N. A., Putnam, J. E., Jacobsen, L. B., Nichols, D. E., \& Mclaughlin, J. L. (1982). Brine Shrimp: A Convenient General Bioassay for Active Plant Constituents. Journal of Medicinal Plant Research, 45, 31-34.

Mohamed, S., Hashim, S. N., \& Rahman, A. (2012). Seaweeds: A Sustainable Functional Food for Complementary and Alternative Therapy. Trends in Food Science \& Technology, 23(2), 83-96. https://doi.org/10.1016/j.tifs.2011.09.001

Nguyen, T. Van, Ueng, J.-P., \& Tsai, G.-J. (2011). Proximate Composition, Total Phenolic Content, and Antioxidant Activity of Sea grape (Caulerpa lentillifera). Journal of Food Science, 76 (November), C950-c958. https://doi.org/10.1111/j.17503841.2011.02289.x

Okeke, M. ., Iroegbu, C. ., Eze, E. ., Okoli, A. ., \& Esimone, C., (2001). Evaluation of Extracts of Root of Landonphin owerrience for Antibacterial Activity. Journal of Ethnopharmacology, 78, 119127. https://doi.org/10.1016/S03788741(01)00307-5

Paul, J. V., Littler, M. M., Littler, S. D., \& Fenical, W. (1987). Evidence for Chemical Defense in Tropical Green Alga Caulerpa ashmeadii (Caulerpacease: Chlorophyta): Isolation of New Bioactive Sesquiterpenoids. Journal of Chemical Ecology, 13(5), 1171-1185. 
Ratana-arporn, P., \& Chirapart, A. (2006). Nutritional Evaluation of Tropical Green Seaweeds Caulerpa lentillifera and Ulva reticulata. Kasetsart J. (Nat. Sci), 40(September), 75-83.

Saengkhae, C., Arunnopparat, W., \& Sungkhajorn, P. (2007). Antioxidative Activity of the Leaf of Nelumbo nucifera Gaertn. on Oxidative Stress-Induced Erythrocyte Hemolysis in Hypertensive and Normotensive Rats. Thai Journal of Physiological Sciences, 20(2), 70-78.

Singh, R. P., \& Kaur, G. (2008). Hemolytic Activity of Aqueous Extract of Livistona chinensis Fruits. Food and Chemical Toxicology, 46, 553-556. https://doi.org/10.1016/j.fct.2007.08.037

Situ, H., \& Bobek, A. L. (2000). In Vitro Assessment of Antifungal Therapeutic
Potential of Salivary Histatin-5, Two Variants of Histatin-5, and Salivary Mucin ( MUC7 ) Domain 1. Antimicrobial Agents and Chemotheraphy, 44(6), 1485-1493.

Sonibare, A. A. A. M. A. (2017). In Vitro Antioxidant Activity, Brine Shrimp Lethality and Assessment of Bioactive Constituents of Three wild Dioscorea Species. Journal of Food Measurement and Characterization, 11(2), 685-695. https://doi.org/10.1007/s11694-0169438-5

Zohra, M., \& Fawzia, A. (2014). Hemolytic Activity of Different Herbal Extracts used in Algeria. International Journal of Pharma Science and Research, 5(08), 495-500. 